Magdalena Bas Vilizzio

Recibido:

Aceptado:

Abstract

Key words

Resumen

Palabras clave
Universidad de Monterrey $\mid$ México | magdalenabas@gmail.com

\section{Ecological sustainability in investment-State dispute settlement: risks of legal pluralism in practice}

\author{
Sostenibilidad ecológica en la solución de controversias \\ inversor-Estado: riesgos del pluralismo jurídico en la práctica
}




\section{International Law fragmentation}

In the last few years the international community has witnessed the fragmentation of International Law into different self-contained regimes, as a result of the diversification and expansion of issues subject to international regulation and the prerogative of the States to be part of international agreements (Nasser, 2015). Selfcontained regimes are spheres of regulation that have their own rules, values, principles and even sources (Lima, 2014, p. 220), which are not necessarily shared by General International Law or other self-contained regimes.

The United Nations International Law Commission, which deeply analysed the topic, arrived at the conclusion that:

[t]he fragmentation of the international social world has attained legal significance especially as it has been accompanied by the emergence of specialized and (relatively) autonomous rules or rule-complexes, legal institutions and spheres of legal practice. What once appeared to be governed by "general international law" has become the field of operation for such specialist systems as "trade law", "human rights law", "environmental law", "law of the sea", "European law" and even such exotic and highly specialized knowledges as "investment law" or "international refugee law" etc. - each possessing their own principles and institutions (United Nations, 2006, p.11).

The existence and the characteristics of these regimes follow the thesis of legal pluralism, rooted in three postulates: 1) the inevitable conflicts resulting from diverse basic norms and legal preconceptions in terms of Kelsen's theory; 2) the need for specialised structures and institutions regarding legal actors' interests, priorities and values; 3 ) the fact that the particular rationality of each self-contained regime is a consequence of social sub-systems (e.g. capital protection - human rights protection) and it can lead to tensions between different sets of norms (Petersmann, 2016). Nevertheless, Drnas de Clèment (2012) argues that taking legal pluralism to the extreme constitutes the antithesis of Law, as it is based on plural interpretations rather than legal hierarchies. Legal pluralism ends with an integral understanding of Law and the principle of justice, especially when self-contained regimes do not coexist harmonically.

The International Law Commission's report presents criteria and interpretation guidelines for the relation between General International Law and self-contained regimes, rather than solving the clash between different self-contained regimes. Investor-State disputes that are directly related to human rights or sustainable ecology are an example of the risks of fragmentation that International Law may undergo. Moreover, low and middle-income countries (LMICs) have fewer resources to deal with investment disputes, thus the most common consequence in these areas is regulatory chill, which impacts public policy space, which in turn is the foundation of regulatory sovereignty (Bas Vilizzio, 2020, pp. 284-288). Although the effect of investorState dispute settlements (ISDS) over public policy space was first pointed out by the UNCTAD in 2003, the institution did not manage to explain its deeper impact on LMICs ${ }^{1}$.

In regard to the latter, the aim of this piece is to identify and analyse investor-State disputes involving LMICs, in which the collision between investment protection and ecological sustainability sets of norms evidence the risks of legal pluralism in International Law. Three cases will be analysed in the following pages: 1) Aguas del Tunari v. Bolivia (International Centre for Settlement of Investment Disputes (ICSID) case No.

\footnotetext{
${ }^{1}$ The report argues that "although host countries already limit their regulatory autonomy as a result of liberalization policies—and have their autonomy limited as part of the wider process of economic globalization-IIAs create distinctive issues in this connection. Such international agreements, like other legal texts, are specifications of legal obligations that limit the sovereign autonomy of the parties." (UNCTAD, 2003, p. 145)
} 
ARB $/ 02 / 3)^{2}$; 2) Pac Rim v. El Salvador (ICSID case No. ARB/09/12) ${ }^{3}$; and 3) Cortec v. Kenya (ICSID case No. ARB/15/29) ${ }^{4}$.

\section{Aguas del Tunari v. Bolivia}

Bolivia is a paradigmatic State regarding investor-State dispute settlement, and the Aguas del Tunari case paved the way for this ${ }^{5}$. The dispute's most remote origin is the privatisation of water and sewage services in Cochabamba under the responsibility of Aguas del Tunari (3 September 1999). A few months after the privatisation process, on 1 December 1999, the company increased the water rates over 50\%, causing significant popular protests which were organised in connection with the Coordination of the Defence of Water and Life. As a result, on 10 April 2000, the government of Bolivia terminated Aguas del Tunari's agreement (Shultz, 2008).

The termination of the contract led the company to file a request for arbitration with the ICSID (November $12,2001)$, on the basis of the Bolivia-Netherlands BIT. In the brief, a compensation of approximately 50 million dollars is claimed, in spite of having invested less than 1 million. On 21 October 2005, the ICSID established its jurisdiction, which Bolivia challenged, alleging that Aguas del Tunari was neither under direct nor under indirect control of Netherlands' nationals.

Due to international public pressure, on 19 January 2006, the company decided to withdraw the case, after agreeing the transfer of their shares to the Bolivian State for the symbolic amount of 2 Bolivianos (approximately USD 0.25) (Bolivia's Ministry of Foreign Relations and Worship, 2008, p. 101). Consequently, the respondent requested that the procedure was terminated (March 28, 2006).

The Aguas del Tunari case represents the first investor-State dispute against Bolivia and the prelude to becoming the first State in the world to withdraw from the ICSID in 2007. The reasons given for leaving the organization are the incompatibility with the Calvo Doctrine incorporated in 1967's Constitution, which was in force at that time; procedural issues (conflicts of interest between the claimants and arbitrators, double jeopardy, free case law, forum shopping, treaty shopping, and cherry picking); the high proceedings costs and the insignificant number of arbitration awards in favour of the States; and the conflicts of interest at the World Bank, in its capacity as a promoter of structural adjustment policies, which led to the privatisation of companies that then claimed substantial compensations due to being nationalised (Foreign Relations and Worship Minister of Bolivia, 2008, pp. 108-124).

In addition, there were significant changes in the country's domestic law, such as section 320 subsection II of the State's Political Constitution (2009), which establishes an absolute isolation clause, given that it does not admit exceptions to the prohibition of submitting disputes against the State to a jurisdiction that is not domestic (Cervantes, 2017, p. 23). The regulation is supplemented by the ninth transitional provision, which gives a four-year term since the election of the new Administration to renegotiate or withdraw from those treaties that were incompatible.

The constitutional mandate resulted in the termination of the BITs with Netherlands, Italy, United States, Spain, France, Germany, Austria, Sweden, Belgium and Luxemburg, and Argentina and Denmark, in chronological order between 1 November 2009 and 13 May 2014 ${ }^{6}$. The Ecuador-Bolivia BIT was unilaterally

\footnotetext{
${ }^{2}$ Related to United Nations' sustainable development goal 6: clean water and sanitation.

${ }^{3}$ Related to United Nations' sustainable development goal 15: life on land, and goal 13: climate action.

${ }^{4}$ Related to United Nations' sustainable development goal 15: life on land, and goal 13: climate action.

${ }^{5}$ For an analysis of South American States position regarding investment protection regimen see: Bas Vilizzio (2017).

${ }^{6}$ UNCTAD Investment Policy Hub Data.
} 
withdrawn by Ecuador, and the BIT binding Bolivia with Cuba, Chile, China, Republic of Korea, Paraguay, Peru, Rumania, Switzerland and the United Kingdom have remained in force, notwithstanding the sunset clauses in the terminated BITs.

\section{Pac Rim v. El Salvador}

The origin of the dispute between Pac Rim Cayman LLC and El Salvador arose from the mining exploitation of silver and gold permits of the Project El Dorado in the department of Cabañas. The Salvadoran companies Pres and Dorex were the holders of exploitation rights of said deposits when the Canadian company, Pac Rim, acquired them in $2002^{7}$. While the mining permits were still valid (they ended on 1 January 2015), shortly after the acquisition, proceedings towards obtaining a new license started. With the request still in process, on 10 March 2008, President Antonio Saca announced that permits for metallic mining projects with no environmental impact diagnostic assessment would not be granted until a new mining law passed. Thus, Pac Rim and other companies' requests remained pending and metallic mining was virtually stopped.

This matter led Pac Rim to file for arbitration at the ICSID (15 June 2009), claiming that they were holders of the mining rights, that they had conducted prospecting, technical and economic feasibility studies, and that they had requested the environmental and gold mining exploitation permits (arbitral award, October 14, 2016, paragraph 3.9). The company stated that the de facto prohibition was a mechanism through which the legal regime in which they trusted and invested was modified. Given that the investment made had lost its value (paragraph 3.6), they requested a 314 million dollar compensation (paragraph 3.31).

The State's answer was blunt: Pac Rim never had the legal rights over the silver and gold deposits at El Dorado, given that the companies that held the rights were acquired shortly before the permits for the new licenses were requested. Even if they had had the legal rights, an investment should always be made in the host State: a principle that the investor disregarded when claiming that the State was obliged to grant the permit. Therefore, Pac Rim could not have requested compensation for damages for the value lost for rights they never had (paragraph 3.22-323).

The other side of the story involves local communities' position in ISDS, especially in the extractive sector. Although local communities may resist investment projects, they are usually "invisible" during arbitration as they have few legal options to be heard (Perrone, 2019). As International Law does not fix this problem, "demands of recognition are articulated in a language that arbitrators distrust: a language of politics, values and aspirations that relate not to the global economy but to the local community" (Perrone, 2021, p. 198).

The Pac Rim case is a clear example of social opposition to a foreign investment project. The point of greatest tension took place when three local environmental advocates were murdered: Marcelo Rivera, Felicita Escheverría and Dora Alicia Resinos Sorto (8 months' pregnant at the time). Although the perpetrators of the crimes were not found, the State's Attorney General understood that there were factors that led to consider that "the homicides and other events may be related and have a common origin" (CIEL, 2014, p. 11).

The Pac Rim's arbitration process was conducted over a period of seven years. The stage related to the merits highlighted two issues: the State's right to regulate the environment and to ensure a healthy environment as a human right, as opposed to the protection of a foreign investment in such a risk sector as mining. The involvement of issues beyond investment protection makes the voice of a civil organised society necessary, a matter that has led authors such as Sornarajah $(2015, \mathrm{p}$. 8) to consider nongovernmental organizations as a countervailing force to corporate power in International Political Economy.

\footnotetext{
${ }^{7}$ For arbitration purposes, Pac Rim acts under the subsidiary Pac Rim Cayman LLC, incorporated in Nevada, United States.
} 
It is useful to observe the brief amicus curiae submitted by the Centre for International Environmental Law (CIEL) on behalf of six organizations members of the National Coalition against Metallic Mining in El Salvador $^{8}$, a coalition of nongovernmental organizations and investigation centres that seek to establish dialogues regarding metal mining issues in El Salvador. The brief emphasises that the actions taken by El Salvador pertain to an international legal framework of environmental and human rights protection that bind the State given that it is a member: the Stockholm Declaration on the Human Environment, principle 1 of the Rio Declaration (1992), article 12 of the International Covenant on Economic, Social and Cultural Rights, and article 11 of the Additional Protocol to the American Convention on Human Rights in the Area of Economic, Social and Cultural Rights.

The court did not consider the brief content in the final award, given that there was consensus between the parties in the dispute for the organizations to access part of the evidence submitted, including the hearing that was not public. Additionally, the court considered that, given the circumstances, CIEL's claims were not to be taken into account. Notwithstanding the foregoing, the claims in the CIEL amicus curiae brief were publicly acknowledged in the system-world and can be considered a demonstration of the risks of International Law fragmentation, especially when human rights are at stake.

In the merit award (October 14, 2016), the court dismisses Pac Rim's claims, due to the fact that, to the date of President Saca's announcement regarding mining activities, the company did not hold any exploitation rights, therefore the claim for damages was not covered by Salvadoran or International Law (paragraphs 10.410.5). As a result, the investor was sentenced to pay USD 8 million plus interests to El Salvador, as a portion of the almost USD 12 million the State had to pay in legal costs (paragraph 12.1 (4)) $)^{9}$.

Once the award was issued, on 29 March, El Salvador's Parliament passed a public order law, which received 69 out of 84 votes, prohibiting soil and subsoil metallic mining. The regulation also established that the proceedings towards mining exploitation were without effect and that existing metallic mines would be closed and environmental remediation for the damage caused would be made. This way, El Salvador became the first State in the world to prohibit metallic mining, a fact that attests to the existence of a regulatory chill during the period of time the arbitration lasted.

\section{Cortec v. Kenya}

The third and last case identified also involves an investment in the mining sector, specifically niobium and rare earth prospecting and exploitation in one of the biggest deposits of the world. The company, British owned Cortec Mining Kenya Limited, had been investing in the Mrima Hill project in Kenya since 2007. For this purpose, they had obtained Special Prospecting License 256 (4 April 2008, renewed twice until its termination on 1 December 2014), which authorised the fulfilment of prospecting activities in the area, and Special Mining License 351 (March 3, 2013) which exclusively authorised the company to exploit the area for 21 years.

Notwithstanding, in August, 2013, the recently assumed government of President Uhuru Kenyatta investigated the mining licensing process during the so-called "transition period" (January 15 to May 15, 2013) for alleged authority abuse during the previous Mining Commissioner’s activities, Moses Masibo. License num-

\footnotetext{
${ }^{8}$ Asociación de Comunidades para el Desarrollo de Chalatenango (CCR); Asociación de Desarrollo Económico y Social (ADES); CORDES; Asociación para el Desarrollo de El Salvador (CRIPDES); Fundación para el Estudio de la Aplicación de la Ley (FESPAD); Unidad Ecológica Salvadoreña (UNES).

${ }^{9}$ Payments were made on July 2, 2017; two months after the El Salvador's Supreme Court of Justice ordered a preventive seizure for seven bank accounts of the company. The company had to pay 8.097.072 dollars, in accordance with the interest rate established in the ICSID notice dated March 28, 2017.
} 
ber 351 granted to Cortec was among the reviewed licenses. The investigation determined that the aforementioned license had been issued fourth months before the approval of the environmental impact evaluation, which in accordance with Kenya's Domestic Law (Mining and environmental impact regulation) is a prerequisite for obtaining any exploitation license. Consequently, the license was "revoked", in the company's words, or "suspended", in the State's words (award dated 22 October 2018, paragraph 3). The announcement was made via national television and on a post in the social network Twitter, without any previous or further formal notice to the company (award, paragraph 2).

In view of the above, on July 7, 2015, Cortec requested the ICSID Secretariat that a registration of a request for arbitration be made against Kenya, on the grounds that the State expropriated their investment without fair compensation (USD 2000 million) in accordance with article 5 of the United Kingdom-Kenya BIT ${ }^{10}$. Similar to the Pac Rim case, the State responded decisively: the mining company did not hold exploitation rights in compliance with a legally obtained license; thus an investment expropriation did not exist. In the same way, foreign investors are obliged to comply with the host country's domestic law and the investor had acted in bad faith.

In the award dated 22 October 2018, the ad hoc court considered that the investor had acted in bad faith and that there was no sufficient evidence to accept the corruption accusation of the former Mining Commissioner. Notwithstanding the foregoing, the court took a stance in favour of Kenya's position regarding the obligation to comply with domestic law, especially taking into consideration that the investment analysed was a legal construct pursuant to Kenyan law (award, paragraph 222). Hence, if the mining license was void ab initio, it could not constitute an investment protected by the United Kingdom-Kenya BIT (award, paragraph 333). Overall, the court rejected Cortec's complaint and ordered the payment of their portion of the arbitration costs and half of the costs claimed by the State ${ }^{11}$.

Whereas Kenya did not recover the entirety of the money spent during the procedure, the case remains relevant for two reasons. Firstly, because the Court acknowledges the enforceability of compliance with domestic regulations even if the BIT does not so regulate it specifically, though there are no explicit references to the right to regulate or the authority of State police to create regulations ${ }^{12}$ in areas of public interests and in valid exercise of its sovereignty. Secondly, this case and the aforementioned cases are solid examples of the collision between the protection of investments regime and other international regimes related to ecological sustainability, such as international human rights protection or environment protection frameworks.

\section{Final remarks}

The three aforementioned disputes resemble other investor-State disputes in which foreign investors questioned public policies made in order to protect human rights, public health or ecological sustainability. For instance, Philip Morris v. Uruguay (tobacco control measures, ICSID case No. ARB/10/7); Eco Oro v. Colombia (environmental measures in Paramo of Santurban, ICSID case No. ARB/16/41); Vattenfall v. Germany (nuclear power phase-out, ICSID case No. ARB/12/12); Piero Foresti v. South Africa (equality right in post-apartheid Constitution, ICSID case No. ARB(AF)/07/01).

Secondly, in the three cases the awards were in favour of the States' interests. Nevertheless, the arbitration did not go unnoticed to them, as they did not recover all of the legal or arbitration costs. These budgetary resources could have been used for different goals, such as education, public health, or environmental

\footnotetext{
${ }^{10}$ It was the first and only suit known against Kenya.

${ }^{11}$ At this time, the case is in the process of partial annulment of the arbitral award requested by the investor.

${ }^{12}$ This idea is more recently developed in the arbitral award of July 8th, 2016, in the Philip Morris versus Uruguay case (ICSID case No. ARB/10/7). For a further analysis see: Bas Vilizzio and Michelini (2019).
} 
measures, usually more urgent priorities for LMICs. Additionally, the lack of experience in the system, as well as the time and human resources that should be dedicated to the disputes, are factors that may have regulatory chill effects on other situations and other States.

The risks of legal pluralism are evidenced. However, the fact that international ad hoc courts act as external bodies of legal control of the State's activity or inactivity (Hernández, 2017, p. 23) deepens the consequences. They are competent to determine the existence or non-existence of State's responsibility and possible compensation, even in the case of measures regarding public policy space, the basis of regulatory sovereignty. This tension is even more dangerous in health emergencies, such as the covid-19 syndemic ${ }^{13}$ (Bas Vilizzio, 2020b).

All in all, the fact remains that the claims were not refused by the arbitration institutions because of the direct connection with ecological sustainability and human rights, the monetary resources involved for LMICs, the exclusion of the right to regulate as well as the regulatory chill in the awards. This reveals that the main problem lies not in the cases but in the system itself.

\section{References}

Bas Vilizzio, M. (2020). Estado-empresas transnacionales: cambios en el régimen de solución de controversias inversor-Estado y redefinición de la soberanía a la luz de la protección de los derechos humanos. Relaciones Internacionales, 29(59), 271-294. https://doi.org/10.24215/23142766e116

Bas Vilizzio, M. (2020b). Las respuestas a la COVID-19 en el laberinto de la solución de controversias inversor-estado. Análisis Carolina 46/2020. Fundación Carolina. https://doi.org/10.33960/AC 46.2020

Bas Vilizzio, M. (2017). América del Sur ante los tratados bilaterales de inversion: ¿hacia un retorno del Estado en la solución de controversias? Comisión Sectorial de Investigación Científica, Universidad de la República. https://www.csic.edu.uy/sites/csic/files/bas_vilizzio america del sur frente a los tratados bilaterales de inversion fder.pdf

Bas Vilizzio, M. and Michelini, F. (2019). Arbitraje de inversiones y derechos humanos: un análisis particular del caso Philip Morris contra Uruguay. Comisión Sectorial de Investigación Científica, Universidad de la República. https://www.csic.edu.uy/sites/csic/files/Bas\%20Vilizzio_Arbitraje $\% 20 \mathrm{de} \% 20$ inversiones $\% 20 \mathrm{y} \% 20$ derecho\%20humanos $\% 20 \mathrm{Un} \% 20$ an $\% \mathrm{C} 3 \% \mathrm{~A} 1 \mathrm{li}$ sis\%20particular\%20del $\% 20$ caso $\% 20$ Philip $\% 20$ Morris\%20contra $\% 20$ Uruguay FDER.pdf

Cervantes, A. (2017). Nuevo Constitucionalismo Latinoamericano y Arbitraje de Inversión. Spain arbitration review: revista del Club Español del Arbitraje, 30, 2017, 81-100.

CIEL (2014). Amicus curiae, Pac Rim v. El Salvador, ICSID Case No. ARB/09/12. July 25, 2014. https://www.ciel.org/wp-content/uploads/2014/06/PacRim_AmicusEng 25Jul2014.pdf

Drnas de Clèment, Z. (2012). Derechos Especiales/Regímenes Autónomos y El Derecho Internacional. Estudios de Derecho Internacional y de Derecho Europeo en homenaje al profesor Manuel Pérez González, I. Tirant lo Blanch.

\footnotetext{
${ }^{13}$ As Horton argues, COVID-19 is a syndemic, a term conceived by Singer (2009) to introduce the social and economic causes and effects of a virus spread.
} 
Hernández, J. I. (2017). Regulación Económica y Arbitraje Internacional De Inversiones. RED: Revista Electrónica de Direito. https://www.cije.up.pt/download-file/1534

Horton, R (2020). Offline: COVID-19 is not a pandemic. The Lancet, 396 (10255), 874.

https://doi.org/10.1016/S0140-6736(20)32000-6

Lima, G. (2014). Conceitos de relações internacionais e teoria do direito diante dos efeitos pluralistas da globalização: governança global, regimes jurídicos, direito reflexivo, pluralismo jurídico, corregulação e autorregulação. Revista de Direito Internacional 11(1), 215-228. https://core.ac.uk/download/pdf/79125119.pdf

Foreign Relations and Worship Minister of Bolivia (2008). Bolivia y el CIADI: crónica de un divorcio anunciado. Baldomir, S. and Santos, C. (eds), Soberanía de los pueblos o intereses empresariales. Fundación Solón, Redes Amigos de la Tierra, Uruguay Sustentable, Amigos de la Tierra.

Nasser, S. (2015). Direito Global em pedaços: fragmentação, regimes e pluralismo Revista de Direito Internacional, 12(2), 98-126. https://doi.org/10.5102/rdi.v12i2.3707

Perrone, N. (2021). Investment treaties and the legal imagination. How foreign investors play by their own rules. Oxford University Press.

Perrone, N. (2019). The "Invisible" Local Communities: Foreign Investor Obligations, Inclusiveness, and the International Investment Regime. AJIL Unbound, 113, 16-21. http://doi.org/10.1017/aju.2018.92

Petersmann, E. U. (2016). How to reconcile Health Law and Economic Law with human rights? Administration of justice in tobacco control disputes. Asian Journal of WTO \& International Health Law and Policy 10(2), 27-78.

Shultz, J. (2008). La guerra del agua en Cochabamba y sus secuelas. Shultz, J. and Crane, M. (eds), Desafiando la globalización Historias de la experiencia boliviana. The Democracy Center, Plural Editores.

Singer, M. (2009). Introduction to syndemics. A critical systems approach to public and community health. Jossey-Bass.

Sornarajah, M. (2015). Resistance and Change in the International Law on Foreign Investment. Cambridge University Press.

United Nations (2006) Fragmentation of international law: difficulties arising from the diversification and expansion of international law. Report of the Study Group of the International Law Commission, A/CN.4/L.682. https://legal.un.org/ilc/documentation/english/a_cn4 1682.pdf 